\title{
ANALYSIS OF THE QUALITY OF LIFE IN PATIENTS SUBMITTED TO ONCOLOGICAL TREATMENT OF THE HEAD AND NECK
}

\author{
ANÁLISE DA QUALIDADE DE VIDA EM PACIENTES SUBMETIDOS AO \\ TRATAMENTO ONCOLÓGICO DE CABEÇA E PESCOÇO
}

\begin{abstract}
Janaína Santos PAULISTA ${ }^{1}$; Bianca Sakamoto Ribeiro PAIVA ${ }^{2}$; Carlos Eduardo PAIVA ${ }^{3}$; Marco Antonio de OLIVEIRA ${ }^{4}$; Maria Helena BARBOSA ${ }^{5}$; Elizabeth BARICHELLO ${ }^{6}$

1. Federal University of Triângulo Mineiro - UFTM, Graduate Program in Health Care PPGAS, Uberaba, MG, Brazil; 2. Learning and Research Institute, Barretos Cancer Hospital, Health-Related Quality of Life Research Group, Barretos, São Paulo, Brazil; 3 Learning and Research Institute, Barretos Cancer Hospital, Health-Related Quality of Life Research Group, Barretos, São Paulo, Brazil; 4. Statistician, Barretos Cancer Hospital, Barretos, SP, Brasil; 5. Institute of Health Sciences at UFTM, Uberaba, MG, Brazil. 6. Associate Professor of Nursing of the Institute of Health Sciences Federal University of Triângulo Mineiro, Uberaba, MG, Brazil. lizabarichello@hotmail.com
\end{abstract}

\begin{abstract}
To evaluate the quality of life and the influence of sociodemographic and clinical variables in patients undergoing treatment for head and neck cancer. Method: Quantitative, cross-sectional study. Two instruments were used: sociodemographic and clinical questionnaire and the Functional Assessment Cancer Therapy Head Neck (FACT-HN). Results: 170 respondents, 60.6\% male, $51.2 \%$ married, with laryngeal cancer being the most found (34.7\%) of the total sample, $78.8 \%$ underwent surgical procedures. In FACT-HN, the variables that showed significance were: educational level, professional activity and salary income. Only in the subscale additional head and neck cancer specific concerns (HNSC) were significant: type of cancer, staging, chemotherapy and surgical treatment. Conclusions: The research contributes by showing that predictive factors of quality of life are also socioeconomic issues and not just clinical issues related to the therapeutic approach. Assistance planning is essential to provide support for rehabilitation and reintegration into society.
\end{abstract}

KEYWORDS: Combined Modality Therapy. Health-Related Quality of Life. Head and Neck Neoplasms. Oncology Nursing.

\section{INTRODUCTION}

Chronic non-communicable diseases (CNCD), with emphasis on diseases of the circulatory system, neoplasms, chronic respiratory diseases and diabetes, correspond to 36 million $(63 \%)$ of deaths and illness in the world population. According to the World Health Organization (WHO), about $80 \%$ of deaths from CNCDs occur in low or middle income countries (BRASIL, 2011; WORLD HEALTH ORGANIZATION, 2014). In Brazil, these diseases account for $72 \%$ of the causes of death, with $16.3 \%$ corresponding to neoplasms, affecting more intensively individuals belonging to vulnerable groups, such as the elderly and those with low education and income (MALTA et al., 2014).

In the coming decades, demographic and epidemiological transitions indicate that cancer will have an increasing impact (FERLAY et al., 2015). It is estimated that in 2030 the global cancer incidence will be 27 million cases and the number of deaths will reach 17 million annually. In Brazil, the National Cancer Institute foresees for 2020/2022, 625 thousand new cases for each year, with the exception of non-melanoma skin cancer. The most frequent neoplasms are: prostate, female breast, colon and rectum, lung and cervix (BRASIL, 2019).

Head and neck cancer (HNC) represents approximately $5 \%$ of the cases of malignant tumors and occupies the fifth position in the list of most common neoplasms in the world, with a worldwide incidence of 780 thousand new cases per year, among these, $1.7 \%$ corresponds to the population of Brazil (FERLAY et al., 2015; PERDOMO et al., 2016).

Among the tumors of the HNC when those of the oral cavity, larynx and thyroid, there is cancer of the oral cavity as the seventh most common type in men, with a risk of 10.69 new cases per 100 thousand men and 3.71 of each 100 thousand women. Laryngeal cancer occupies the first position and represents the second most common type of respiratory cancer in the world, second only to lung cancer. In Brazil, laryngeal neoplasia occupies the eighth position with estimates of 6.470 new cases in men for the 2020-2022 triennial. In women, thyroid cancer is in fifth place with an estimated 11.950 cases per 100 thousand women (CASATI et al., 2012; BRASIL, 2019). 
The incidence of $\mathrm{HNC}$ increases with age and its occurrence is higher in people over 50 years old, being up to 3 to 4 times more frequent in men than in women and more common in blacks. In females, an increase in recent years has been attributed to the greater number of alcoholic smokers (SIMARD; TORRE; JEMAL, 2014; PERDOMO et al., 2016). It is known that the use of tobacco and alcohol simultaneously increases the risk of developing cancer by up to 30 times and that infection by the Human Papilloma Virus is also strongly correlated with the appearance of oropharyngeal tumors. In young patients the presence of these tumors is rarer, with only $4 \%$ to $6 \%$ of cases (CASATI et al., 2012; COMBES; FRANCESCHI, 2014; FERLAY et al., 2015).

The treatment of HNC depends on the type of tumor, location and extent, and is often invasive. This can be done by different therapeutic modalities such as radiotherapy, chemotherapy and surgery, which can be used exclusively or associated (TUOMI et al., 2017). Each of these modalities will cause the patient side effects and / or functional consequences (breathing problems, swallowing and verbal communication), aesthetic (mutilating surgeries) and psychosocial (social isolation), in the face of conduct that may aim at curing or relieving symptoms (FÚRIA, 2006; TUOMI et al., 2017).

It is understood that the malignant tumor of the head and neck is a disease that introduces several changes with a significant impact on quality of life, correlating determinants and multifactorial conditions of health, which include economic, sociocultural aspects, personal experience and the patient's lifestyle. The assessment of health-related quality of life (HRQOL) thus becomes a complex issue due to its characteristics of subjectivity and multidimensionality, in addition to the lack of a gold standard. (FÚRIA, 2006).

It is believed that the application of quality of life questionnaires can serve as a subsidy to detect situations such as depression, alcoholism and risk of incapacity for work, and can be used to target more comprehensive clinical and social support measures. This assessment must be incorporated into clinical practice, thus being able to demonstrate the nature and extent of the problems faced by the patient during the course of the disease (ROGERS et al., 2010; TUOMI et al., 2017).

Given this scenario, conducting research on HRQOL in patients with head and neck cancer is essential to list the affected aspects and further plan nursing interventions for rehabilitation based on a real understanding of the impact of the disease (FREIRE et al., 2014). Thus, this study aimed to assess the quality of life and the influence of sociodemographic and clinical variables in patients undergoing treatment for head and neck cancer using the Functional Assessment Cancer Therapy Head Neck instrument (FACT-HN).

\section{METHOD}

Quantitative research with cross-sectional design, with 170 patients, developed in a Cancer hospital in the interior of São Paulo, from March to June 2015. Patients aged 18 years or older, diagnosed with head and neck cancer, histologically proven, were included only in the following primary sites: oral cavity tumors, laryngeal tumors and thyroid tumors, undergoing cancer treatment (surgery and / or chemotherapy and / or radiotherapy) in the last five years or who were being followed up after treatment (follow up).

To calculate the sample size, a correlation was made between the predictor variables equal to $0.10\left(\mathrm{R}^{2}=0.10\right)$ in a multiple linear regression $\alpha=0.05$ model with five predictors, with a type I error and type II error of significance $\beta=0.1$, resulting in statistical power a priori of 90\%. Using the GPower v.3.0.10 application, the values described above were introduced, obtaining a sample size of $n=154$. Considering a sampling loss of $10 \%$ (refusal to participate), the final number of interview attempts was $\mathrm{n}=170$. The dependent variable in each model will be the score for the domain studied, that is, for each domain there will be a specific model.

Two instruments were used to obtain data: the sociodemographic and clinical questionnaire and the FACT-HN - Functional Assessment Cancer Therapy Head Neck instrument.

The first questionnaire containing exploratory data was designed to characterize the sample and gathers variables related to sociodemographic factors, tumor characterization and treatment adopted, as described in Table 1. This questionnaire was submitted to content and appearance validation by professionals with experience in thematic.

The second instrument, FACT-HN, is a specific and multidimensional HRQOL questionnaire for patients with head and neck cancer. This was subjected to translation and structural adaptation into Portuguese, following the guidelines of the Functional Assessment Chronic Illness Therapy (FACIT) and has sensitivity to assess people with cancer in the acute or late stage of treatment. In FACT-HN there is the FACT-G 
questionnaire plus five subscales: physical wellbeing, social / family well-being, emotional wellbeing, functional well-being and additional head and neck cancer specific concerns (HNSC). In each subscale there are seven items being evaluated with a score from zero to 28 , except for the specific subscale that evaluates twelve items with a score from zero to 36 . The subscales generate three global indexes (TOI, FACT-G and FACT-HN) to analyze quality of life, the higher the score, the better the quality of life in relation to the measured domain (FÚRIA, 2006).

The Trial Outcome Index (TOI) domain encompasses physical and functional well-being and additional specific concerns in $\mathrm{HNC}$, with a score from zero to 92. The FACT-G, which involves physical, social / family, emotional and functional well-being, has a score of zero to 108 and the FACT-HN that involves physical, social / family, emotional, functional well-being and additional specific concerns in $\mathrm{HNC}$ with a score from zero to 144) (FÚRIA, 2006).

For data analysis, a database was created in the Excel ${ }^{\circledR}$ program; validated by double typing. Then, they were imported into the program "Statistical Package for the Social Sciences" (SPSS 20.0) for processing and analysis. Using nonparametric tests, Mann-Whitney and KruskalWallis, verified the association between sociodemographic and clinical variables with the quality of life score in all domains and in their global associations (TOI, FACT-G and FACT- HN). In this article, the result of a dissertation, it was decided to go over the results generated by the global domains and the HNSC subscale because it contributes with specific questions about the sample pathology. To verify the association between the participant's age at the time of collection with each domain, a graphical analysis using the scatter plot as well as the Spearman correlation coefficient were performed.

This investigation started after approval by the Research Ethics Committee with opinion number 928/2015 and followed all the rigor of Resolution No. 466/2012.

\section{RESULTS}

A result of 107 patients was interviewed with HNC. Before the sociodemographic and clinical questionnaire, $103(60.6 \%)$ patients were male. Regarding age, there was an average of 55.3 years for oral cavity cancer. Laryngeal cancer had the highest mean of 60.61 years, whereas in thyroid cancer there was the lowest mean (46 years) and the lowest minimum age (22 years). Of these 94 $(55.3 \%)$ reported coming from São Paulo, 87 $(51.2 \%)$ were married and $96(57.1 \%)$ were white, $72(42.9 \%)$ considered themselves non-white (blacks, browns, Asians and others). As for religion, expressively 124 patients $(72.9 \%)$ declared themselves to be Catholic. In the items ethnicity and religion, 02 patients chose not to answer one of the options presented. All other items were answered by 170 patients.

When asked about their educational level, 68 patients $(40 \%)$ had completed elementary school, $41(24.1 \%)$ completed high school and $6(3.1 \%)$ were illiterate. Of the total sample, $116(68.2 \%)$ patients do not have an employment contract, including working from home (housewife). Those in professional activity stand out: general services with $37(24.3 \%)$, and rural workers (farmers) with 26 (17.1\%). Wage income remained in the monthly range of two to three minimum wages in 75 of the cases $(44.1 \%)$.

Given the distribution of clinical characteristics, laryngeal cancer stands out in 59 $(34.7 \%)$ patients, followed by oral cavity cancer $(32.9 \%)$ and thyroid cancer (32.4\%). Staging I was the most frequently found $(\mathrm{n}=56 ; 32.9 \%)$, however, it was observed that there was no marked difference in the sample stages.

Relevantly, 134 (78.8\%) patients underwent a surgical procedure, $94 \quad(55.3 \%)$ received radiotherapy treatment, which was adjuvant to the others. Chemotherapy treatment was performed only by $51(30 \%)$ individuals, also mostly in adjuvant form. The status prominently showed that 110 $(64.7 \%)$ patients were being followed up at the time of collection and $73(42.9 \%)$ had up to one year of treatment.

Regarding the variables of tobacco and alcohol, 61 patients (35.9) had never smoked and $109(64.2 \%)$ had already used tobacco. In smokers, $53(31.2 \%)$ stopped using tobacco after the diagnosis of cancer, 18 (10.6) did not stop using it with the diagnosis and $38(22.4 \%)$ had already stopped smoking before receiving the diagnosis. Of those who smoked at some point in life, 103 (95.4\%) consumed tobacco in the form of smoke.

Regarding the consumption of alcoholic beverages, 79 patients $(46.5 \%)$ declared that they never ingested. Of the alcohol consuming portion, $38.8 \%$ stopped drinking before treatment and $14.7 \%$ remained in consumption. Those who used alcohol specifically consumed it in distilled (drip) and fermented (beer) forms.

The HRQOL measured using the FACT-HN was considered satisfactory. In table 1 , given the 
total scores for each domain, there is the general quality of life (FACTG) with an average of 73.87, the TOI with 55.03 and the FACT-HN 96.39, with a median of 98 points. The most affected functions were the subscales: emotional / family well-being and physical well-being.

Table 1. Result of the descriptive analysis of the HRQOL instrument (FACT-HN), Barretos, SP, Brazil, 2015

\begin{tabular}{lccc}
\hline & Average (DP) & $\begin{array}{c}\text { Median } \\
\text { (min- max) }\end{array}$ & Cronbach's alpha \\
\hline PWB (Physical) & $20.84(6.31)$ & $23.00(0-28)$ & 0.807 \\
EWB(Emotional) & $22.57(4.64)$ & $23.33(4-28)$ & 0.722 \\
SFWB (SociallFamiliar) & $8.79(4.78)$ & $7.00(0-20)$ & 0.586 \\
BFunc (Functional) & $21.66(5.33)$ & $23.00(4-28)$ & 0.787 \\
HNSC (Additional Preocup.) & $22.52(7.13)$ & $23.00(4-34)$ & 0.327 \\
FACT-HN & $96.39(16.19)$ & $98.00(50-127)$ & - \\
TOI & $65.03(15.6)$ & $67.00(18-88)$ & - \\
FACTG & $73.87(11.5)$ & $76.00(40-97)$ & - \\
\hline
\end{tabular}

Initially to verify the association between sociodemographic and clinical variables with the quality of life score in their global associations and in the HNSC subscale, the non-parametric tests, Mann-Whitney and Kruskal-Wallis were applied considering the significance level of $20 \%(\mathrm{p}<0.2)$ in order to avoid loss of information.

The Spearman correlation (non-parametric coefficient) used due to the Gaussian distribution of times, showed that there was statistical significance for the variable age in the HNSC domains ( $\mathrm{p}=$ $0.003)$ and in the TOI $(p=0.169)$, considering $p$ $<0.2$.
In tables 2 and 3, there is this univariate analysis, which shows that the variables marital status and religion, were the only ones that had no significant value in any of the domains. The others go on to compose the multiple linear regression models.

In tables 4 and 5 , there is the result of multiple linear regressions. This model was adjusted by the sequential mode using the Enter variable selection method, where a level of $5 \%(\mathrm{p}<0.05)$ of significance is considered and from then on, the simultaneous influence of independent variables on quality of life was verified. 
Table 2. Distribution of sociodemographic data in univariate analysis, Barretos, SP, Brazil, 2015

\begin{tabular}{|c|c|c|c|c|c|c|c|c|}
\hline \multirow[t]{2}{*}{ Variables } & \multirow{2}{*}{$\begin{array}{c}\text { HNSC }^{\ddagger} \\
\text { Average (SD) }\end{array}$} & \multicolumn{3}{|c|}{ toi $^{\$}$} & \multirow{2}{*}{$\begin{array}{c}\text { fact-g } \\
\text { Average (SD) }\end{array}$} & \multicolumn{3}{|c|}{ fact-hn" } \\
\hline & & $\mathrm{p}$ & Average (SD) & $\mathrm{P}$ & & $\mathrm{P}$ & Average (SD) & $\mathrm{P}$ \\
\hline \multicolumn{9}{|l|}{ Sex } \\
\hline Male & $21.7(6.83)$ & $0.042 *$ & $65.3(14.60)$ & $0.99 *$ & $74.2(11.64)$ & $0.529 *$ & $95.9(15.60)$ & $0.458^{*}$ \\
\hline Female & $23.7(7.47)$ & & $64.5(17.11)$ & & $73.3(11.36)$ & & $97.0(17.10)$ & \\
\hline \multicolumn{9}{|l|}{ Ethnicity } \\
\hline White & $23.3(7.15)$ & $0.101 *$ & $67.9(14.91)$ & $0.005^{*}$ & $75.5(11.22)$ & $0.009 *$ & $98.9(16.14)$ & $0.013 *$ \\
\hline Non white & $21.4(7.12)$ & & $61.2(15.96)$ & & $71.6(11.68)$ & & 93.1(15.96) & \\
\hline \multicolumn{9}{|l|}{ Marital status } \\
\hline Single & $25.0(7.44)$ & & $66.9(14.73)$ & & $70.7(11.79)$ & & $95.7(16.10)$ & \\
\hline Married & $22.3(6.83)$ & & $65.6(15.25)$ & & $75.4(11.47)$ & & $97.7(15.84)$ & \\
\hline Stable union & $21.4(7.81)$ & $0.355 \dagger$ & $63.1(16.90)$ & $0.905 \dagger$ & $76.1(10.24)$ & $0.133 \dagger$ & $97.5(16.18)$ & $0.699 \dagger$ \\
\hline Widow & $21.3(8.22)$ & & $62.8(20.47)$ & & $72.1(13.02)$ & & $93.4(18.42)$ & \\
\hline Divorced & $22.2(6.96)$ & & $63.7(15.49)$ & & $70.8(11.16)$ & & $93.0(17.03)$ & \\
\hline \multicolumn{9}{|l|}{ Religion } \\
\hline Catholic & $22.8(7.00)$ & $0.297 *$ & $65.8(14.55)$ & $0.474 *$ & $74.0(10.79)$ & $0.8628^{*}$ & $96.9(15.02)$ & $0.744 *$ \\
\hline Non catholic & $21.5(7.48)$ & & $62.8(18.17)$ & & $73.3(13.37)$ & & $94.8(19.09)$ & \\
\hline \multicolumn{9}{|l|}{ Educational level } \\
\hline Illiterate & $17.1(6.04)$ & & $50.2(16.69)$ & & $64.8(12.83)$ & & $81.9(16.57)$ & \\
\hline Elementary & $21.5(6.88)$ & $0.00 \dagger$ & $64.2(14.32)$ & $<0.001 \dagger$ & $73.3(10.81)$ & $0.005 \dagger$ & $94.8(14.53)$ & $0.000 \dagger$ \\
\hline Complete high school & $23.6(6.89)$ & & $66.9(14.38)$ & & $75.2(11.94)$ & & $98.9(16.30)$ & \\
\hline Higher education & $25.8(6.75)$ & & $71.8(15.04)$ & & $77.8(8.63)$ & & $103.6(14.0)$ & \\
\hline \multicolumn{9}{|l|}{ Professional activity } \\
\hline In activity & $25.7(6.50)$ & $0.00 \dagger$ & $70.5(14.78)$ & $0.001 *$ & 76.3(11.77) & $0.019 *$ & $102.0(16.4)$ & $0.000 *$ \\
\hline Unemployed & $21.0(6.95)$ & & $62.4(15.37)$ & & $72.7(11.25)$ & & $93.7(15.45)$ & \\
\hline \multicolumn{9}{|l|}{ Income } \\
\hline$<2$ salaries & $20.1(7.28)$ & $<0.001 \dagger$ & $58.5(16.02)$ & $<0.001 \uparrow$ & $69.4(12.92)$ & $0.001 \dagger$ & $89.5(17.01)$ & $<0.0001$ \\
\hline$\geq 2$ and $\leq 3$ salaries & $22.7(6.65)$ & & $67.1(14.54)$ & & $75.9(10.22)$ & & $98.7(14.70)$ & \\
\hline$>3$ salaries & $27.5(4.86)$ & & $74.5(11.62)$ & & $78.4(9.86)$ & & $105.9(12.7)$ & \\
\hline
\end{tabular}

* Mann-Whitney test; $\uparrow$ Test Kruskal-wallis;

${ }^{\sharp}$ hnsc- subscale of additional concerns; ${ }^{\S}$ toi- final total index; ${ }^{\|}$general total fact-g-score general total; ${ }^{\circledR}$ fact-hn-total score 
Table 3. Distribution of clinical data in univariate analysis, Barretos, SP, Brazil, 2015.

\begin{tabular}{|c|c|c|c|c|c|c|c|c|}
\hline \multirow[b]{2}{*}{ Variables } & \multicolumn{2}{|l|}{ HNSC $^{\ddagger}$} & \multicolumn{2}{|c|}{$\operatorname{toi}^{8}$} & \multirow{2}{*}{$\begin{array}{c}\text { fact-g } \\
\text { Average(SD) }\end{array}$} & \multicolumn{3}{|c|}{ fact-hn" } \\
\hline & Average(SD) (dp) & $\mathrm{p}$ & Average(SD) & $\mathrm{p}$ & & $\mathrm{p}$ & Average(SD) & $\mathrm{p}$ \\
\hline \multicolumn{9}{|l|}{ Type of cancer } \\
\hline Oral cavity & $20.0(7.06)$ & $<0,001 \dagger$ & $62,3(15,05)$ & $0,030 \uparrow$ & $74,1(11,61)$ & $0,331 \dagger$ & $94,2(15,65)$ & $\mathbf{0 , 0 0 4}$ \\
\hline Larynx & $21.5(6.84)$ & & $63,3(16,82)$ & & $71,7(12,39)$ & & $93,2(17,03)$ & \\
\hline Thyroid & $26.0(6.16)$ & & $69,5(14,04)$ & & $75,8(10,16)$ & & $101,9(14,57)$ & \\
\hline \multicolumn{9}{|l|}{ Staging } \\
\hline I & $24.6(7.48)$ & & $68,4(15,90)$ & & $75,6(11,58)$ & & $100,2(16,78)$ & \\
\hline II & $23.8(6.36)$ & & $67,4(13,74)$ & & $75,6(9,42)$ & & $99,5(12,89)$ & \\
\hline III & $22.1(6.08)$ & $<0,001 \uparrow$ & $64,2(14,27)$ & $0,011 \dagger$ & $72,2(11,35)$ & $0,181 \dagger$ & $94,3(14,61)$ & $0,003 \dagger$ \\
\hline IV & $17.8(6.47)$ & & $57,4(16,55)$ & & $70,4(13,24)$ & & $88,3(17,72)$ & \\
\hline \multicolumn{9}{|l|}{ Surgery } \\
\hline No & $20.0(7.10)$ & $0,019 *$ & $60,4(16,41)$ & $0,079 *$ & $71,5(13,46)$ & $0,161 *$ & $91,7(17,84)$ & $0,059 *$ \\
\hline Yes & $23.1(7.02)$ & & $66,1(15,25)$ & & $74,4(10,94)$ & & $97,6(15,56)$ & \\
\hline \multicolumn{9}{|l|}{ Radiotherapy } \\
\hline No & $25.2(6.40)$ & $<0,001 *$ & $67,7(14,80)$ & $0,064 *$ & $75,0(10,85)$ & $0,281^{*}$ & $100,4(15,29)$ & $0,002 *$ \\
\hline Yes & $20.3(6.98)$ & & $62,8(15,93)$ & & $72,9(11,97)$ & & $93,0(16,22)$ & \\
\hline \multicolumn{9}{|l|}{ Chemotherapy } \\
\hline No & $24.0(7.01)$ & $<0,001 *$ & $66,2(16,78)$ & $0,020 *$ & $73,8(11,68)$ & $0,993 *$ & $97,5(17,04)$ & $0,045 *$ \\
\hline Yes & $18.8(6.06)$ & & $61,9(12,20)$ & & $73,9(11,28)$ & & $93,5(13,71)$ & \\
\hline \multicolumn{9}{|l|}{ Status } \\
\hline Treatment & $20.6(6.98)$ & $0,007 *$ & $60,3(15,01)$ & $0,001 *$ & $71,1(12,35)$ & $0,007 *$ & $91,8(15,68)$ & $0,001 *$ \\
\hline Follow up & $23.5(7.03)$ & & $67,5(15,40)$ & & $75,3(10,80)$ & & $98,8(15,99)$ & \\
\hline \multicolumn{9}{|l|}{ Treatment time } \\
\hline$\leq 12$ months & $21.4(6.92)$ & $0,034 \dagger$ & $60,8(16,21)$ & $0,003 \dagger$ & $70,3(12,12)$ & $0,004 \dagger$ & $91,8(16,37)$ & $0,002 \dagger$ \\
\hline$>12 \leq 36$ months & $21.7(7.72)$ & & $65,6(14,21)$ & & $75,9(11,34)$ & & $97,6(15,73)$ & \\
\hline$>36$ months & $24.6(6.55)$ & & $70,3(14,58)$ & & $77,0(9,54)$ & & $101,6(14,84)$ & \\
\hline
\end{tabular}


Table 1. Final multiple linear regression model HNSC and toi, Barretos, SP, Brazil, 2015

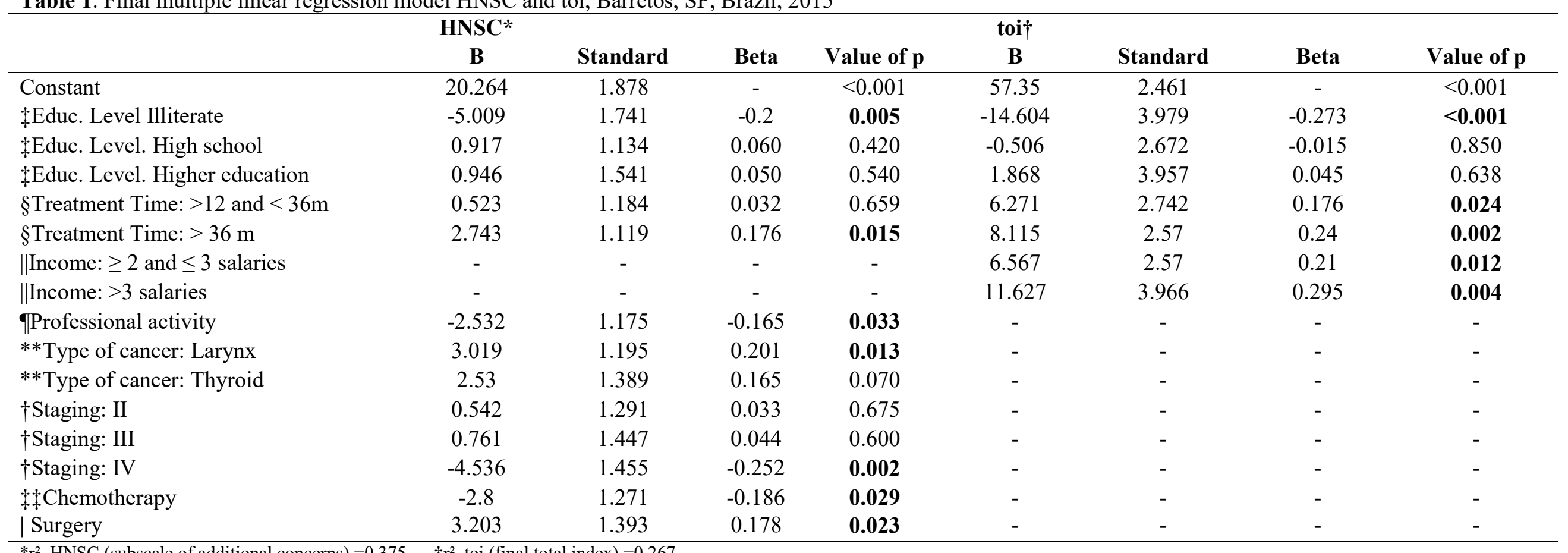

$* \mathrm{r}^{2}$ HNSC (subscale of additional concerns) $=0,375 \quad \forall \mathrm{r}^{2}$ toi (final total index) $=0,267$

$\$$ Variable educational level, reference and basic education; $\S$ Variable treatment time, reference is $<12$ months;

$\|$ Variable wage income, reference is $<2$ wages; $\uparrow$ Variable professional activity, reference is to be in activity;

**Variable type of cancer, reference is cancer of the oral cavity; $\uparrow \dagger$ Staging variable, reference is staging I;

t+Chemotherapy variable, reference is not having performed this treatment; |Variable surgery, reference is not having performed this treatment; 
Table 2. Final multiple regression model fact-g and fact-hn, Barretos, SP, Brazil, 2015

\begin{tabular}{|c|c|c|c|c|c|c|c|c|}
\hline & \multirow{2}{*}{$\begin{array}{c}\text { fact-g* } \\
\text { B }\end{array}$} & \multirow[b]{2}{*}{$\begin{array}{l}\text { Standard } \\
\text { error }\end{array}$} & \multirow[b]{2}{*}{ Beta } & \multicolumn{3}{|c|}{ facthn $\dagger$} & \multirow[b]{2}{*}{ Beta } & \multirow[b]{2}{*}{ Value of $p$} \\
\hline & & & & Value of $p$ & B & $\begin{array}{l}\text { Standard } \\
\text { error }\end{array}$ & & \\
\hline Constant & 67.497 & 1.940 & - & 0 & 87.197 & 2.586 & - & 0 \\
\hline †duc. Level Illiterate & -8.137 & 3.310 & -0.191 & 0.015 & -12.408 & 4.181 & -0.223 & 0.003 \\
\hline †Educ. Level. High school & -0.371 & 2.090 & -0.015 & 0.860 & 0.745 & 2.807 & 0.021 & 0.791 \\
\hline †Educ. Level. Higher education & 1.506 & 3.099 & 0.048 & 0.628 & 3.376 & 4.157 & 0.078 & 0.418 \\
\hline$\S$ Treatment Time: $>12$ and $<36 \mathrm{~m}$ & 6.466 & 2.165 & 0.240 & 0.003 & 7.253 & 2.88 & 0.195 & 0.013 \\
\hline$\S$ Treatment Time: $>36 \mathrm{~m}$ & 6.151 & 2.027 & 0.242 & 0.003 & 8.544 & 2.70 & 0.243 & 0.002 \\
\hline$\|$ Income: $\geq 2$ and $\leq 3$ salaries & 5.430 & 2.033 & 0.232 & 0.008 & 7.198 & 2.70 & 0.221 & 0.009 \\
\hline |Income: $>3$ salaries & 6.256 & 3.112 & 0.212 & 0.046 & 11.526 & 4.167 & 0.281 & 0.006 \\
\hline
\end{tabular}

$* r^{2}$ fact- $\mathrm{g}$ (total overall score) $=0.203 \quad * \mathrm{r}^{2}$ fact-hn (total score) $=0.254$

\$Variable educational level, reference and basic education; §Variable treatment time, reference is $<12$ months;

|| Variable wage income, reference is $<2$ wages - of which Brazil minimum wage R $\$ 788.00$ - Decree 8,381 / 2014 of 12/29/2014 
For TOI, FACT-G and FACTHN, the statistically significant variables were the same: educational level, length of treatment and salary income. It is observed that the illiterate patient has a decrease in the quality of life in relation to the one who has elementary education, being for the TOI domain $\mathrm{p}<0.001$, in FACT-G $\mathrm{p}=0.015$ and in FACTHN $p=0.003$. Regarding the duration of treatment, quality of life is better for those who had a period longer than twelve months of therapy. Wage income also positively influenced HRQOL for those who had more than 2 minimum wages. In the HNSC subscale, there was a decrease in the quality of life of those who declared themselves illiterate $(p=0.005)$, but different from the global domains, this decrease also occurred in those who were without professional activity $(p=0.003)$ at the time of the interview, for those who had IV staging $(\mathrm{p}=0.002)$ and had chemotherapy treatment $(\mathrm{p}=$ $0.029)$. Quality of life was found to be better for those with laryngeal cancer ( $p=0.013$ ) compared to those who had cancer of the oral cavity, as well as those who underwent a surgical procedure compared to those who did not undergo this treatment modality $(\mathrm{p}=0.023)$.

\section{DISCUSSION}

Focusing on the assessment of HRQOL in patients with head and neck cancer covers the physical, psychological, mental, spiritual and social domains, which therefore go beyond biological disease. Numerous studies have aimed to evaluate these aspects to favor the understanding of the real impact that the disease and the treatment bring, mainly in relation to the alterations caused by the surgery that in itself brings a mutilatory characteristic (FÚRIA, 2006; MELO FILHO et al., 2013).

In this study, HRQOL was assessed using the FACTH-HN instrument in line with other studies in the literature (FÚRIA, 2006; MELO FILHO et al., 2013). The choice for this instrument was due to its multidimensional and easy application, translated into Portuguese with specificities of the HNC. In addition, it is not restricted to a therapeutic period, so it can be used before and / or after treatment, as well as during the course of the disease itself. The interviews had an average time of 20 minutes, carried out in their entirety by the author, with analysis in its three global indexes (TOI, FACT-G and FACTHN) and in the HNSC.

Research has been carried out for HNC particularly for laryngeal tumors (FÚRIA, 2006;
MACIEL et al., 2013; ROSSI, 2014), and in this work, one sought to expand the collection by analyzing, in addition to laryngeal tumors, those of the oral cavity and thyroid that were being treated or followed up in a referral oncology hospital. This choice was based on the increased incidence of these tumors (BRASIL, 2019; PERDOMO et al., 2016; SIMARD; TORRE; JEMAL, 2014).

In the characterization of the 170 patients in the sample, there was a predominance of males, married, with a past history of alcohol and tobacco use, low socioeconomic status, low level of education and with the average age for each type of cancer consistent with the literature (MACIEL et al., 2013; GALBIATTI et al., 2013., PEDROSA et al., 2019).

Clinically they are patients who were mostly outpatients, and randomly covered the three types of tumors surveyed. They presented laryngeal neoplasia $34.7 \%$ of patients, cancer of the oral cavity $32.9 \%$ and thyroid $32.4 \%$. Therefore, there was no discrepancy between the types of neoplasms and this also occurred in relation to staging, with $32.9 \%$ being in stage I, $25.3 \%$ in stage II, $21.2 \%$ in stage III and stage IV with $20.6 \%$. It is necessary to show that a reference hospital for cancer treatment was chosen as the collection field, which provides public and free care through the Unified Health System (UHS). This fact, consequently, contributed to the study logistics to be carried out without difficulties, adding to the sample the most incident neoplasms of the $\mathrm{HNC}$ according to estimates. In 2014 , this reference center, according to its hospital record, had 11022 visits, 938 of which were only for patients with HNC.

It is known that HRQOL is centered on the subject's subjective assessment, on the perception of the impact of clinical and non-clinical aspects that influence health (RAO; ABRAHAM; MEENA, 2018). In the interviewed patients, through the analysis of the global FACTHN scores, it was found that this quality of life was seen as satisfactory, having a similar result with other studies that used the same questionnaire (FÚRIA, 2006).

It should be noted that in the subscale social / family well-being (SFWB), present in the sum of the global domains FACTHN and FACT-G, it is questioned how the patient feels in front of family and friends, if there is an emotional support network and a acceptance of the current situation. In this research, this item had the worst average among the other subscales, scoring 8.79 with a standard deviation of 4.78 , which suggests a deficit in the sample family support network. 
When verifying the influence of all sociodemographic and clinical factors, TOI, FACT$\mathrm{G}$ and FACTHN presented a similar result. Educational level, treatment time and salary income were considered significant in the sample's QoL, unlike other studies where clinical factors were more significant (FÚRIA, 2006).

For many diseases, including cancer, the correlation that social determinants such as education, occupation, income, gender and ethnicity have on prevalence and risk factors is undeniable. The CNCD epidemic affects more low-income people as they are more exposed to risk factors and less access to health services, in addition to these pathologies create a vicious circle that leads families to a greater state of poverty (BRASIL, 2011). This data is in line with what was seen in the sample, as in relation to the educational level, there was significance in the univariate analysis and in linear regression in all domains. It was evident that for illiterate patients there is a decrease in the overall quality of life FACT-G $(p=0.015)$, functional TOI $(p<0.001)$, general for HNC FACTHN $(p=0.003)$, in addition to HNSC $(p=0.005)$. Thus, in the face of patients with a higher educational level, consequently greater possibility of better jobs, financial resources and benefits to treat health, in addition to retirement. These facts may be responsible for the best HRQOL in patients who completed high school $(24.1 \%)$ and higher education (13.5\%) (FÚRIA, 2006; MELO FILHO et al., 2013; MACIEL et al., 2013).

This decrease also occurred in those with an income below two minimum wages and who were in the first year of treatment. It is noteworthy that, professionally, the classification was higher in: general services, self-employed and rural worker farmer, which partially corroborates with another study (CASATI et al., 2012). The HNC's relationship with social inequalities and were evidenced in research conducted in several countries, the association between the risk of oral cancer with a low socioeconomic condition (BOING; ANTUNES, 2011). Therefore, it is believed that knowing the sociodemographic factors during a $\mathrm{HNC}$ treatment is essential for the team in conducting and following care.

The fact of having a professional activity or not is also an important non-clinical factor for patients with $\mathrm{HNC}$. In the specific domain HNSC, this item showed significance in linear regression $(p$ $=0.033)$. In this way, $68 \%$ of the patients who declared to be without a job (including working at home / home) have a decrease in quality of life in relation to those who have a job.
In the study, age was significant only in the univariate analysis of the specific HNSC domain ( $p$ $=0.003)$ and in the general TOI domain $(p=0.169)$. Thus, there was no significance in HRQOL, but it is still an interesting data in view of the different means it presented, which presupposes different approaches during treatment.

Despite the multifactorial aspect of the disease, tobacco and alcohol in simultaneous consumption are the factors with the greatest carcinogenic potential (SZYMAŃSKA et al., 2011). In the literature studies of QoL that analyze smoking in the $\mathrm{HNC}$, it was seen that it can be associated with FACT-HN and FACT-G, however this association in the multivariate analysis remains only for FACT-G (MACIEL et al., 2013). Thus, this association can happen in the three global domains (FÚRIA, 2006). In both, the result was different from the sample of the study in question, as these variables did not have significant values in the final analysis of any domain.

The HNSC presents the item: "H\&N8Cigarette Smoke or Other Cigarette Products" and "H\&N9-Such as Alcoholic Beverages (e.g., Beer, Wine, etc.)" which also presented significance only in the univariate analysis. It is known that smoking cessation generates benefits to the patient at any stage of life and it is believed that the fact that patients in this sample, in their majority (31.2\%), chose to stop smoking and alcoholism by associating it with cancer has influenced this result. Years ago, smoking was associated with status and glamour, as well as the feeling of belonging to a certain group, but today the social perception of its use has changed and this is visible in the reduction of the number of smokers in the world and the growing intention to quit.

Recent data indicates a total percentage of $14.7 \%$ of adult smokers, and in the period from 1989 to 2010 there was a drop of $46 \%$ in the percentage of smokers due to the Smoking Control Policies that were implemented, so it is estimated that about 420,000 deaths were prevented in this period (LEVY; ALMEIDA; SZKLO, 2012).

Head and neck tumors usually also result in some degree of speech dysfunction, swallowing, breathing, as well as disfigurement of appearance. It is understood that changes in function and appearance can have a significant impact on selfimage, with the possibility of reaching the psychosocial area of the patient's life (ROSA et al., 2018; PAULA; SAWADA, 2015; KRAAIJENGA et al., 2015). The HNSC domain targets issues related to the HNC and therefore one chose to include it in the description next to the general scales, among 
other items, it also evaluates the image issue. In the study, the HNSC was highlighted by pointing out six predictor variables of HRQOL: educational level, professional activity, type of cancer, staging, and surgery and treatment time.

It should be highlighted that only in HNSC, the clinical variables (type of cancer, staging and surgery) were statistically significant. This data corroborates the literature, because as a rule, more advanced tumors require multimodal treatment (surgery, radiotherapy and chemotherapy), which consequently may lead to sequelae, determining a worse HRQOL (GALBIATTI et al., 2013).

Specifically in the study, patients with laryngeal neoplasia presented better HRQOL. This result can be associated with multi-professional follow-up, since patients, without exception, were referred to the outpatient clinic with the speech therapy team. This follow-up is of utmost importance because it aims to preserve or readapt the individual's communication functions, softening the sequels and consequently the impact on HRQOL (CAMPOS; LEITE, 2010).

The surgery was also a predictor of a better quality of life in the HNSC field compared to other treatments. It is the main treatment option for primary, secondary and recurrent disease. With new surgical techniques, such as robotic surgery, there is a reduction in the tracheostomy rate, which allows a faster recovery in basic functions such as oral swallowing, as well as shorter hospitalizations (GALBIATTI et al., 2013; RAO; ABRAHAM; MEENA, 2018).

Radiotherapy was the second most used treatment choice, since $55.3 \%$ received radiotherapy, which was adjuvant to the others. Today, intensity modulated radiotherapy (IMRT) is used, which is seen as advantageous compared to traditional techniques such as conventional radiotherapy and conformal radiotherapy, offering more homogeneous dosage coverage and a reduction in tissue exposure adjacent to the treatment. The higher the dose, the greater the control of the tumor is and the better the survival rate (PAULA; SAWADA, 2015; KRAAIJENGA et al., 2015; CAMPOS; LEITE, 2010).

Studies show that stability usually occurs after twelve months of treatment, minimizing treatment sequelae and directing further adaptation through rehabilitation programs (FÚRIA, 2006; ROGERS et al., 2010; MACIEL et al., 2013). For all domains this was a significant variable, showing precisely this better quality of life from the 12 months onwards.

Evaluating the quality of life and knowing the socioeconomic and clinical profile of patients with $\mathrm{HNC}$ who are under treatment or in follow-up provides the nursing team and the entire health care team with subsidies to improve care planning and consequently to perform effective actions of selfcare and acceptance of the pathology. Through these HRQOL researches, the nurse will be able to base decision making with the interdisciplinary team and define behaviors that go beyond the biomedical or fragmented view in the treatment.

\section{CONCLUSION}

The research contributed by showing that quality of life predictors are also socioeconomic issues and not only clinical issues related to the therapeutic approach. The discussions on the subject pervade how to develop the treatment with less repercussion of the cancer symptoms, how to mitigate or prevent sequelae, but little is analyzed if this patient has socioeconomic and educational conditions to perform guidance and maintain selfcare behaviors from the therapeutic approach.

Inequalities in health reflect social inequalities and this is an aspect that cannot be minimized. Socioeconomic indicators are predictors of neoplasm prognosis and HNC tumors are included. Extrinsic factors such as educational level and salary income will directly influence each patient's QoL, regardless of the level of excellence in surgical, radiotherapy or chemotherapy treatment offered.

Identifying the preponderant factors may offer the interdisciplinary team, sensitivity and focus on issues that go beyond the biological and would go unnoticed until they cause physical damage. The team will have knowledge and access to public policies, support networks and social interaction aiming to contribute to a better quality of life.

\section{ACKNOWLEDGEMENTS}

This study was financed in part by the Coordenação de Aperfeiçoamento de Pessoal de Nível Superior - Brasil (CAPES) - Finance Code 001 
RESUMO: Objetivo: Avaliar a qualidade de vida e a influência de variáveis sociodemográficas e clínicas, nos pacientes submetidos ao tratamento de câncer de cabeça e de pescoço. Método: Estudo quantitativo, transversal. Foram utilizados dois instrumentos: questionário sociodemográfico e clínico e o instrumento Functional Assessment Cancer Therapy Head Neck (FACT-HN). Resultados: 170 entrevistados, $60,6 \%$ do sexo masculino, $51,2 \%$ casados, sendo o câncer de laringe o mais encontrado $(34,7 \%)$ do total da amostra, 78,8\% realizaram procedimento cirúrgico. No FACT-HN, as variáveis que apresentaram significância foram: nível educacional, atividade profissional e renda salarial. Apenas na subescala preocupações adicionais específicas do câncer de cabeça e pescoço (PACP) foram significativos: tipo de câncer, estadiamento, tratamento quimioterápico e cirúrgico. Conclusões: A pesquisa contribui ao evidenciar que fatores preditores de qualidade de vida são também questões socioeconômicas e não apenas questões clínicas relacionadas a abordagem terapêutica. O planejamento da assistência é fundamental para fornecer um suporte com vistas a reabilitação e reinserção na sociedade.

PALAVRAS-CHAVE: Enfermagem Oncológica. Qualidade de vida relaciona a saúde. Neoplasias de Cabeça e Pescoço. Tratamento.

\section{REFERENCES}

BOING, A. F.; ANTUNES, J. L. F. Socioeconomic conditions and head and neck cancer: a systematic literature review. Ciência \& Saúde Coletiva, Rio de Janeiro, v. 16, n. 2, p. 615-622, feb. 2011. https://doi.org/10.1590/S1413-81232011000200025.

BRASIL. Ministério da Saúde. Instituto Nacional do Câncer José Gomes Alencar. Estimativa 2020: incidência de Câncer no Brasil. Rio de Janeiro: INCA; 2019. Disponível em:

https://www.inca.gov.br/sites/ufu.sti.inca.local/files//media/document//estimativa-2020-incidencia-de-cancerno-brasil.pdf. Acesso em: 02 fev. 2020.

BRASIL. Ministério da Saúde. Secretaria de Vigilância em Saúde. Departamento de Análise de Situação de Saúde. Plano de ações estratégicas para o enfrentamento das doenças crônicas não transmissíveis (DCNT) no Brasil, 2011-2022. Brasília: Ministério da Saúde, 2011. Disponível em: http://bvsms.saude.gov.br/bvs/publicacoes/plano_acoes_enfrent_dent_2011.pdf. Acesso em: 15 mar. 2019.

CAMPOS, R. J. D. S.; LEITE, I. C. G. Quality of life and voice after radiotherapy: speech therapy repercussions. Revista CEFAC, São Paulo, v. 12, n. 4, p. 671-677, jul./aug. 2010. https://doi.org/10.1590/S1516-18462010005000038.

CASATI, M. F. M. et al. Epidemiologia do câncer de cabeça e pescoço no Brasil: estudo transversal de base populacional. Revista Brasileira de Cirurgia de Cabeça e Pescoço, São Paulo, v. 41, n. 4, p. 186-191, out./dez. 2012. Disponível em: https://www.sbccp.org.br/wp-content/uploads/2014/11/REVISTA-SBCCP-414-artigo-07.pdf. Acesso em: 29 jan. 2019.

COMBES, J-D.; FRANCESCHI, S. Role of human papillomavirus in non-oropharyngeal head and neck cancers. Oral Oncology, Oxford, v. 50, n. 5, p. 370-379, may. 2014.

https://doi.org/10.1016/j.oraloncology.2013.11.004.

FERLAY, J. et al. Cancer incidence and mortality worldwide: Sources, methods and major patterns in GLOBOCAN 2012: Globocan 2012. International Journal of Cancer, New York, v. 136, n. 5, p. e359-e386, mar. 2015. https://doi.org/10.1002/ijc.29210.

FREIRE, M. E. M. et al. Qualidade de vida relacionada à saúde de pacientes com câncer avançado: uma revisão integrativa. Revista da Escola de Enfermagem USP, São Paulo, v. 48, n. 2, p. 357-367, 2014. http://www.scielo.br/pdf/reeusp/v48n2/pt_0080-6234-reeusp-48-02-357.pdf. 
FÚRIA, C. L. B. Qualidade de vida em pacientes tratados de câncer de cavidade oral, faringe e laringe em São Paulo: estudo multicêntrico. Radiologia Brasileira, São Paulo, v. 39, n. 4, p. 252, jul./ago. 2006. https://doi.org/10.1590/S0100-39842006000400016.

GALBIATTI, A. L. S. et al. Head and neck cancer: causes, prevention and treatment. Brazilian Journal of Otorhinolaryngology, São Paulo, v. 79, n. 2, p. 239-247, mar./apr. 2013. https://doi.org/10.5935/18088694.20130041.

KRAAIJENGA, S. A. C. et al. Prospective clinical study on long-term swallowing function and voice quality in advanced head and neck cancer patients treated with concurrent chemoradiotherapy and preventive swallowing exercises. European Archives of Oto-Rhino-Laryngology, Heidelberg, v. 272, n. 11, p. 3521-3531, nov. 2015. https://doi.org/10.1007/s00405-014-3379-6.

LEVY, D.; ALMEIDA, L. M.; SZKLO, A. The Brazil simsmoke policy simulation model: the effect of strong tobacco control policies on smoking prevalence and smoking-attributable deaths in a middle income nation. PLoS Medicine, San Francisco, v. 9, n. 11, p. e1001336, nov. 2012. https://doi.org/10.1371/journal.pmed.1001336.

MACIEL, C. T. V. et al. Análise da qualidade de vida dos pacientes com câncer de laringe em hospital de referência na região Sudeste do Brasil. Revista CEFAC, São Paulo, v. 15, n. 4, p. 932-940, jul./ago. 2013. https://doi.org/10.1590/S1516-18462013000400022.

MALTA, D. C. et al. Mortalidade por doenças crônicas não transmissíveis no Brasil e suas regiões, 2000 a 2011. Epidemiologia e Serviços Saúde, Brasília, v. 23, n. 4, p. 599-608, out/dez. 2014. https://doi.org/10.5123/S1679-49742014000400002. Acesso em: 25 jan. 2019.

MELO FILHO, M. R. et al. Quality of life of patients with head and neck cancer. Brazilian Journal of Otorhinolaryngology, São Paulo, v. 79, n. 1, p. 82-88, jan./feb. 2013. https://doi.org/10.5935/18088694.20130014.

PAULA, J. M.; SAWADA, N. O. Health-related quality of life of cancer patients undergoing radiotherapy. Revista RENE, Fortaleza, v. 16, n. 1, p. 106-113, apr. 2015. https://doi.org/10.15253/21756783.2015000100014.

PEDROSA, M. T. et al. Avaliação clínica dos sintomas de pacientes com câncer de cabeça e pescoço. Avances en Enfermería, Bogotá, v. 37, n. 2, p. 158-168, 2019. https://doi.org/10.15446/av.enferm.v37n2.73149.

PERDOMO, S. et al. Head and neck cancer burden and preventive measures in Central and South America. Cancer Epidemiology, Amsterdam, v. 44, suppl 1, p. s43-s52, sep. 2016. https://doi.org/10.1016/j.canep.2016.03.012.

RAO, K. M.; ABRAHAM, T. T.; MEENA, L. A comparative study of quality of life outcomes in head and neck cancer patients following curative treatment. Indian Journal of Applied Research, Gujarat, v. 8, n. 6, p. 33-37, jan. 2018. https://wwjournals.com/index.php/ijar/article/view/4938/4884. jan. 2019.

ROGERS, S. N. et al. The physical function and social-emotional function subscales of the University of Washington Quality of Life Questionnaire. Archives of Otolaryngology - Head \& Neck Surgery, Chicago, v. 136, n. 4, p. 352-357, apr. 2010. https://doi.org/10.1001/archoto.2010.32.

ROSA, M. E. et al. Correlation between the voice handicap and swallowing quality of life in patients with laryngeal cancer submitted to chemoradiotherapy. CoDAS, São Paulo, v. 30, n. 2, p. e20170060, 2018. http://www.scielo.br/pdf/codas/v30n2/2317-1782-codas-30-2-e20170060.pdf. 
ROSSI, V. C. Larynx cancer: quality of life and voice after treatment. Brazilian Journal of

Otorhinolaryngology, São Paulo, v. 80, n. 5, p. 403-408, sep./oct. 2014.

https://doi.org/10.1016/j.bjorl.2014.07.005.

SIMARD, E. P.; TORRE, L. A.; JEMAL, A. International trends in head and neck cancer incidence rates: differences by country, sex and anatomic site. Oral Oncology, Oxford, v. 50, n. 5, p. 387-403, may. 2014. https://doi.org/10.1016/j.oraloncology.2014.01.016.

SZYMAŃSKA, K. et al. Alcohol and tobacco, and the risk of cancers of the upper aerodigestive tract in Latin America: a case-control study. Cancer Causes \& Control, Oxford, v. 22, n. 7, p. 1037-1046, jul. 2011. https://doi.org/10.1007/s10552-011-9779-7.

TUOMI, L. et al. Voice range profile and health-related quality of life measurements following voice rehabilitation after radiotherapy; a randomized controlled study. Journal of Voice: Official Journal of the Voice Foundation, New York, v. 31, n. 1, p. 115.e9-115.e16, jan. 2017.

https://doi.org/10.1016/j.jvoice.2016.03.012.

WORLD HEALTH ORGANIZATION. Global status report on noncommunicable diseases 2014: attaining the nine global noncommunicable diseases targets; a shared responsibility. Geneva: WHO, 2014.

https://apps.who.int/iris/bitstream/handle/10665/148114/9789241564854_eng.pdf;jsessionid=5A22994905BAB CBBB671E2007A8AE95B?sequence=1. 